\title{
STUDI KOMPARATIF KUALITAS PELAYANAN BELLBOY DI HOTEL AXANA PADANG DALAM MELAYANI TAMU INDIVIDU DAN TAMU GRUP
}

\author{
Fikri Adib Putra ${ }^{1}$,Ira Meirina Chair ${ }^{2}$ \\ Program Studi D4 Manajemen Perhotelan \\ Jurusan Pariwisata \\ FPP Universitas Negeri Padang \\ email: fikriadib33@gmail.com
}

\begin{abstract}
This study aims to describe and compare service quality by bellboy at The Axana Hotel Padang. The research is quantitative descriptive with a comparative approach. The sample used was purposive sampling which was 189 individual guests dan group guests who had stayed at The Axana Hotel Padang, using a questionnaire with a likert scale that had been tested for validity and reliability. Data analysis techniques using statistical tests with Chi Square. The result obtained are as follows: (1) The service of quality by bellboy in serving individual guests at The Axana Hotel Padang Hotel obtained an average score of 3.00 with a good category. (2) The service of quality by bellboy in serving group guests at The Axana Hotel Padang obtained an average score of 3.02 with a good category. (3) Comparison of service quality by bellboy in serving individual guests and group guests at The Axana Hotel Padang shows the results of the test analysis obtained by $P$ value $(0.000<0.05$ Ho hypothesis is refused. That means there is difference in the service of quality by bellboy at The Axana Hotel Padang Hotel in serving individual guests and group guests.
\end{abstract}

\section{Keywords: Service of Quality, Bellboy, Comparative Study}

\section{Pendahuluan}

Hotel adalah suatu badan usaha yang bergerak dalam bidang jasa akomodasi yang dikelola secara komersial. Di dalam hotel para tamu mendapatkan layanan penginapan, makanan dan minuman, serta fasilitas lainnya". Salah satu layanan yang diterima tamu pada saat menginap yaitu layanan bellboy dalam menyambut tamu serta pengantaran barang ke kamar (luggage up). Kualitas merupakan suatu kondisi dinamis yang berpengaruh dengan produk, jasa, manusia, proses dan lingkungan yang memenuhi atau melebihi harapan (Tjiptono, 2001). Sehingga definisi kualitas pelayanan dapat diartikan sebagai upaya pemenuhan kebutuhan dan keinginan konsumen serta ketepatan penyampaiannya dalam mengimbangi harapan konsumen (Tjiptono, 2007).

Gaspersz (2002: 181), mendefinisikan "Kualitas adalah totalitas dari karakteristik suatu produk (barang dan atau jasa) yang menunjang kemampuan untuk memenuhi kebutuhan yang dispesifikasikan”. 
Sedangkan menurut Davis, dalam (Yamit, 2005: 8) membuat definisi kualitas yang lebih luas cakupannya, yaitu kualitas merupakan suatu kondisi dinamis yang berhubungan dengan produk, jasa, manusia, proses, dan lingkungan yang memenuhi atau melebihi harapan. Kualitas yang baik bukan berdasarkan sudut pandang atau persepsi pihak penyedia jasa, tetapi sudut pandang konsumen. Konsumenlah yang menentukan berkualitas atau tidaknya pelayanan yang diterima. Dengan demikian, baik tidaknya kualitas itu tergantung pada kemampuan penyedia jasa dalam memenuhi harapan konsumen secara konsisten.

Kualitas pelayanan ini sangat dipengaruhi oleh harapan konsumen. Harapan ini sangat bervariasi, mulai dari konsumen satu dengan lainnya meskipun pelayanan yang diberikan konsisten. Istilah pelayanan ini berasal dari kata "layan", artinya menolong menyediakan segala yang dibutuhkan orang lain. Karena pada dasarnya pelayanan sangat dibutuhkan manusia, bahkan pelayanan tidak dapat dipisahkan dengan kehidupan manusia (Sinambela, 2010: 3). Pelayanan ialah proses pemenuhan kebutuhan yang dilakukan langsung melalui aktivitas orang lain (Moenir, 2006: 16-17). Pelayanan itu adalah suatu proses kegiatan yang abstrak (intangible), karena menghasilkan produk berupa pelayanan yang diberikan kepada konsumen.

Gaspersz (2002: 181$)$, mendefinisikan "Kualitas adalah totalitas dari karakteristik suatu produk (barang dan atau jasa) yang menunjang kemampuan untuk memenuhi kebutuhan yang dispesifikasikan". Kualitas mungkin dapat dilihat sebagai suatu kelemahan jika konsumen memiliki harapan yang terlalu tinggi, walaupun dengan suatu pelayanan yang baik. Menurut Wyckoff dalam (Purnama, 2006: 19) memberikan pengertian mengenai kualitas layanan sebagai tingkat kesempurnaan untuk memenuhi keinginan konsumen. Sedangkan menurut Parasuraman, dalam (Purnama, 2006: 19) kualitas layanan merupakan perbandingan antara layanan yang dirasakan (persepsi) konsumen dengan kualitas layanan yang diharapkan konsumen. Jika kualitas layanan yang dirasakan sama atau melebihi kualitas layanan yang diharapkan, maka layanan dikatakan berkualitas dan memuaskan.

Hotel memiliki departemen operasional yang karyawannya saling bekerjasama dan berinteraksi langsung dengan tamu dalam memberikan pelayanan yang berkualitas seperti halnya front office. Bagian yang memiliki petugas yang bertanggungjawab dalam melayani kedatangan dan mengurus barang tamu serta mengantarnya bersama tamu ke kamar ditangani oleh bellboy. Bellboy merupakan petugas hotel yang mempunyai tugas dan tanggung jawab membantu mengangkut barang bawaan tamu pada saat check-in maupun checkout ke dan dari kamar hotel (Endar Sugiarto, 1997: 48). 
Kota Padang merupakan salah satu daerah di Sumatera Barat yang sangat ramai dikunjungi wisatawan, sehingga banyak hotel yang didirikan di kota ini, diantaranya yaitu Hotel Axana Padang. Hotel ini berbintang empat dengan memiliki 171 kamar. Berdasarkan hasil observasi peneliti serta berdasarkan pengalaman sewaktu peneliti magang, ditemukan masalah yang dikeluhkan seperti adanya tamu complain dikarenakan bellboy yang bertugas berpakaian/grooming tidak rapi, jadi terkesan tidak sesuai dalam melayani tamu.

Selain dari masalah di atas, peneliti juga menemukan adanya tamu complain karena adanya bellboy yang sibuk berbicara dengan menggunakan bahasa daerah dengan karyawan yang lain dari pada menanggapi pertanyaan atau mendengar pertanyaan tamu. Tidak hanya itu, apabila memberikan penjelasan kepada tamu tidak menggunakan tangan melainkan menunjukkan dengan menggunakan mulut, sehingga terkesan tidak sopan.

Sementara itu, berdasarkan observasi peneliti dapatkan dari guest comment, terdapat complaint ketika tamu grup banyak yang melakukan registrasi/check-in, beberapa tamu meminta membawa barang bawaannya ke kamar dengan menggunakan trolly, akan tetapi setelah lama tamu menunggu, trolly karyawan tersebut tidak datang dikarenakan banyaknya barang yang diantar karyawan ke kamar masing-masing tamu, sehingga tamu tersebut complaint dan membawa sendiri barang bawaanya.
Berdasarkan masalah di atas, didapati banyak complain dari tamu yang pernah menginap pada Hotel Axana Padang. Hal ini akan berdampak buruk pada citra hotel, sehingga berkurangnya tamu yang akan menginap dan tidak tercapainya pendapatan hotel tersebut. Oleh karena itu peneliti berkeinginan untuk menganalisa dan membandingkan kualitas pelayanan yang diberikan oleh bellboy terhadap tamu individu dan tamu grup yang menginap di Hotel Axana Padang. Sehingga dapat diketahui penyebabnya dan ditemukan solusi beserta hasil dari perbandingan tersebut.

Berdasarkan kenyataan yang ada dan mengingat pentingnya kualitas pelayanan, maka peneliti ingin mendeskripsikan dan membandingkan kualitas pelayanan oleh bellboy dalam melayani tamu individu dan tamu grup di Hotel Axana Padang.

\section{Metode Penelitian}

Jenis penelitian ini yaitu deskriptif kuantitatif menggunakan pendekatan komparatif. Sampel yang digunakan purposive sampling yaitu sebanyak 189 orang tamu yang pernah menginap di Hotel Axana Padang, melalui kuesioner dengan skala likert yang validitas dan reliabilitasnya telah teruji. Analisis datanya menggunakan Uji Statistik dengan chi square.

\section{Hasil Penelitian dan Pembahasan}

\section{Kualitas Pelayanan}

Data kualitas pelayanan terdiri dari 19 butir pernyataan, 
dikumpulkan dengan kuesioner yang dibagikan kepada responden/tamu individu dan tamu grup yang menginap di Hotel

Tabel 1. Deskripsi perbandingan kualitas pelayanan oleh bellboy dalam melayani tamu individu dan tamu grup di Hotel Axana Padang

\begin{tabular}{|c|c|c|c|c|c|}
\hline \multirow{2}{*}{ Kategori } & \multirow{2}{*}{$\begin{array}{c}\text { Batas } \\
\text { Interval } \\
\text { Rata-rata }\end{array}$} & \multicolumn{2}{|c|}{ Tamu Individu } & \multicolumn{2}{|c|}{ Tamu Grup } \\
\hline & & $\mathrm{F}$ & $\%$ & $\mathrm{~F}$ & $\%$ \\
\hline Sangat baik & $3,26-4,00$ & 28 & $29.17 \%$ & 0 & $0.00 \%$ \\
\hline Baik & $2,51-3,25$ & 53 & $55.21 \%$ & 45 & $48.39 \%$ \\
\hline Kurang Baik & $1,76-2,50$ & 15 & $15.63 \%$ & 48 & $51.63 \%$ \\
\hline Tidak Baik & $1,00-1,75$ & 0 & $0.00 \%$ & 0 & $0.00 \%$ \\
\hline \multicolumn{2}{|c|}{ Total } & 96 & $100 \%$ & 93 & $100 \%$ \\
\hline
\end{tabular}

Sumber: Data Primer yang diolah, 2018

Tabel diatas menunjukkan perbandingan kualitas pelayanan oleh bellboy di tamu individu sebanyak $28(29.17 \%)$ responden berada pada batas interval 3,26 4,00 dikategorikan sangat baik dan $53(55.21 \%)$ responden berada pada batas interval 2,51 - 3,25 dikategorikan baik dan 15 (15.63) responden berada pada batas interval 1,76 - 2,50. Sedangkan di tamu grup 45 (48.39\%) responden berada pada batas interval 2,51 3,25 dikategorikan baik dan 48 $(51.63 \%)$ responden berada pada batas interval 1,76-2,50.

\section{Analisis Data}

\section{a. Uji Normalitas}

Diperoleh nilai signifikansi untuk kualitas pelayanan oleh bellboy dalam melayani tamu individu sebesar 121 dan tamu grup sebesar 234 dimana taraf signifikansi melebihi 0.05. Sehingga
Axana Padang. Untuk distribusi frekuensi kualitas pelayanan dapat dilihat ditabel dibawah ini: 
kualitas pelayanan bellboy

di Hotel Axana Padang

dalam melayani tamu individu dan tamu grup dapat dilihat pada tabel berikut ini:

Tabel 2. Uji Chi Square Kulitas Pelayanan Bellboy di

Hotel Axana Padang dalam melayani

Tamu Individu dan Tamu grup

Chi-Square Tests

\begin{tabular}{|l|r|r|r|}
\hline & Value & Df & \multicolumn{1}{|c|}{$\begin{array}{c}\text { Asymp. Sig. } \\
\text { (2-sided) }\end{array}$} \\
\hline Pearson Chi-Square & $83.441^{\mathrm{a}}$ & 20 & .000 \\
Likelihood Ratio & 109.393 & 20 & .000 \\
Linear-by-Linear & 48.102 & 1 & .000 \\
Association & 189 & & \\
N of Valid Cases & & & \\
\hline
\end{tabular}

a. 25 cells $(59,5 \%)$ have expected count less than 5 . The minimum expected count is, 49 .

Berdasarkan hasil uji chi square pada tabel di atas diperoleh nilai signifikansi $<0,05$ yaitu 0,000. Maka dapat disimpulkan bahwa dalam penelitian ini berdasarkan uji chi square, Ho ditolak yaitu terdapat perbedaan kualitas pelayanan bellboy di Hotel Axana Padang dalam melayani tamu individu dan tamu grup.

\section{Pembahasan}

Berdasarkan hasil penelitian ini, didapatkan pembahasan tentang kualitas pelayanan oleh bellboy di Hotel Axana Padang, serta perbandingannya.

Penjelasannya sebagai berikut: a. Kualitas Pelayanan oleh bellboy dalam melayani tamu individu

Berdasarkan hasil pengkategorian skor, ratarata variabel dan skor actual yang diperoleh dari garis kontinum mengenai kualitas pelayanan oleh bellboy dalam melayani tamu individu diperoleh hasil distribusi frequensi kualitas pelayanan sebesar 60 $(62.50 \%)$ responden berada pada batas interval 2,51 3,25 dengan kategori baik. Hasil rekapitulasi tanggapan responden berdasarkan 19 item pernyataan tentang kualitas pelayanan yang diajukan diperoleh rata-rata skor sebesar 3,00 pada batas interval 3,26-4,00 dengan 


\begin{abstract}
kategori baik dan berdasarkan skor actual yang diperoleh dari garis kontinum sebesar 5469 berada pada rentang interval antara 4104 - 5472. Hal ini menunjukan bahwa kualitas pelayanan bellboy di Hotel Axana Padang dalam melayani tamu individu tergolong baik.

Hasil analisis deskriptif semua indikator kualitas pelayanan dikategorikan baik. Hal ini menggambarkan bahwa kualitas pelayanan oleh bellboy dalam melayani tamu individu dan tamu grup sudah baik. Sesuai dengan pendapat (Yoeti, 1999: 20) dalam melayani penerima (receiver), harus diperlakukan sebagai Boss atau seorang Raja yang disegani atau ditakuti sehingga tidak berani berbuat tidak ramah.
\end{abstract}

b. Kualitas Pelayanan oleh bellboy dalam melayani tamu grup

Berdasarkan hasil pengkategorian skor, ratarata variabel dan skor actual yang diperoleh dari garis kontinum mengenai kualitas pelayanan oleh bellboy dalam melayani tamu grup diperoleh hasil distribusi frequensi kualitas pelayanan sebesar $\quad 81 \quad(87.10 \%)$ responden berada pada batas interval 2,51 - 3,25 dengan kategori baik. Hasil rekapitulasi tanggapan responden berdasarkan 19 item pernyataan tentang kualitas pelayanan yang diajukan diperoleh rata-rata skor sebesar 3,02 pada batas interval 3,26 - 4,00 dengan kategori baik dan berdasarkan skor actual yang diperoleh dari garis kontinum sebesar 4778 berada pada rentang interval antara 3978 - 5304. Hal ini menunjukan bahwa kualitas pelayanan bellboy di Hotel Axana Padang dalam melayani tamu grup tergolong baik.

Hasil analisis deskriptif semua indikator kualitas pelayanan tergolong baik. Hal ini menggambarkan bahwa kualitas pelayanan yang diberikan oleh bellboy dalam melayani tamu grup sudah baik.

c. Perbandingan Kualitas Pelayanan oleh bellboy di Hotel Axana Padang dalam melayani tamu individu dan tamu grup

Berdasarkan hasil uji hipotesis yang digunakan untuk mengetahui perbandingan kualitas pelayanan oleh bellboy di Hotel Axana Padang dalam 
melayani tamu individu dan

tamu grup berdasarkan pengkategorian skor, ratarata variabel dan skor actual yang diperoleh dari garis kontinum menunjukan bahwa kualitas pelayanan oleh bellboy dalam melayani tamu grup lebih baik dari tamu indivivdu, maka diperoleh hasil uji chi square sebesar 83.441 dan $\mathrm{P}$ value $(0,000<0,05)$ maka Ho ditolak dan Ha diterima, artinya terdapat perbedaan kualitas pelayanan bellboy di Hotel Axana Padang dalam melayani tamu individu dan tamu grup.

Namun perbandingan ini tidak jauh berbeda, kualitas pelayanan oleh bellboy pada kedua tamu ini sudah tergolong sangat baik. Hal ini dikarenakan kualitas pelayanan yang diberikan oleh bellboy pada kedua tamu ini sesuai dengan harapan konsumen. Sesuai dengan pendapat Parasuraman, dalam (Purnama, 2006: 19) kualitas layanan merupakan perbandingan antara layanan yang dirasakan (persepsi) konsumen dengan kualitas layanan yang diharapkan konsumen. Jika kualitas layanan yang dirasakan sama atau melebihi kualitas layanan yang diharapkan, maka layanan dikatakan berkualitas dan memuaskan. Jika pelayanan yang diberikan sudah berkualitas, maka kualitas pelayanan oleh bellboy dalam melayani tamu individu dan tamu grup dapat dikatakan sempurna karena memenuhi keinginan konsumen. Sesuai dengan pendapat Wyckoff dalam (Purnama, 2006: 19) memberikan pengertian mengenai kualitas layanan sebagai tingkat kesempurnaan untuk memenuhi keinginan konsumen.

\section{Kesimpulan dan Saran}

\section{Kesimpulan}

Kualitas pelayanan oleh bellboy dalam melayani tamu individu diperoleh rata-rata skor sebesar 3.00. Sedangkan pada tamu grup diperoleh sebesar 3.02. Rata-rata skor kedua hotel berada pada batas interval 2,51 - 3,25 dikategorikan baik. Selanjutnya perbandingan kualitas pelayanan oleh bellboy dalam melayani tamu individu dan tamu grup dengan menggunakan uji chi square, maka diperoleh hasil uji chi square sebesar 83.441 dan $\mathrm{P}$ value $\quad(0,000<0,05)$ maka Ho ditolak dan Ha diterima, artinya terdapat perbedaan kualitas pelayanan 
bellboy di Hotel Axana

Padang dalam melayani tamu individu dan tamu grup.

\section{Saran}

Diharapkan agar pihak hotel dapat mempertahankan dan meningkatkan kualitas pelayanannya dengan selalu memonitor kerja karyawan tersebut secara berkala dan berkelanjutan agar bisa diketahui apakah pelayanan yang diberikan ole h pihak hotel kepada tamu yang menginap sudah berkualitas dan memuaskan. Monitoring ini dapat dilakukan dengan cara memberikan form guest comment untuk meminta pendapat tamu yang menginap dan sudah menginap atau (check out) dari hotel. Dari guest comment yang dikirimkan kita dapat mengetahui perubahan keinginan tamu sehingga perubahan tersebut secara cepat dapat diantisipasi oleh pihak hotel. Dengan begitu tamu akan merasa puas karena kebutuhannya terpenuhi dan tidak akan berpindah ke hotel lain.

\begin{tabular}{|c|c|c|}
\hline \multicolumn{2}{|c|}{ Disarankan } & kepada \\
\hline seneliti & lainnya & untuk \\
\hline $\begin{array}{l}\text { neneliti } \\
\text { xompara }\end{array}$ & $\begin{array}{l}\text { ntang stud } \\
\text { kepuasan }\end{array}$ & $\operatorname{sum}$ \\
\hline eh & ceptionist, & \\
\hline
\end{tabular}

service dan sebagainya. Karena kepuasan konsumen dipengaruhi oleh kualitas pelayanan yang ada pada hotel yang akan diteliti. Juga disarankan untuk melakukan penelitian lebih dari satu variabel.

\section{DAFTAR PUSTAKA}

Gaspersz, V. 2002. Total Quality Management. Jakarta: PT. Gramedia Pustaka Utama.

Moenir, H. A. S. 2006. Manajemen Pelayanan Umum di Indonesia. Jakarta: PT Bumi Aksara.

Purnama, Nursya'bani. 2006. Manajemen Kualitas: Perspektif Global. Yogyakarta: Ekonisia.

Sinambela. 2010. Reformasi Pelayanan Publik. Jakarta: PT Bumi Aksara.

Sugiarto, Endar dan Sri Sulartiningrum. 1996. Pengantar Akomodasi dan Restoran. Jakarta: PT. Gramedia Pustaka Utama.

Tjiptono, Fandy. 2001. Strategi Pemasaran (Edisi Ketiga). Yogyakarta: Andi, Cetakan Kesatu.

2004.

Manajemen Jasa (Edisi Pertama). Yogyakarta: Andi Offset. 